\title{
PERBEDAAN HASIL BELAJAR MAHASISWA PGSD MENGGUNAKAN MODEL INKUIRI DAN PROJECT BASED LEARNING (PJBL) PADA MATAKULIAH PENDIDIKAN KEWARGANEGARAAN SEKOLAH DASAR
}

\author{
Putri Mahanani \\ Muchtar \\ Prodi PGSD Jurusan KSDP, Fakultas Ilmu Pendidikan \\ Universitas Negeri Malang \\ Email: putri.mahanani.fip@um.ac.id \\ Artikel diterima: 23 April 2019; disetujui: 31 Mei 2019
}

\begin{abstract}
The purpose of the study is to find a comparison between learning outcomes using inquiry and PjBL learning models. The research hypothesis is that there is a difference (Ha) and there is no difference (Ho) in the learning outcomes of PGSD students. This research uses quantitative methods with quasi-experimental research designs. The population studied was all undergraduate students of PGSD Universitas Negeri Malang (UM). Samples were taken by purposive sampling technique. The data analysis technique used the t-test with the help of the SPSS program. The results showed that Ho was accepted so that it could be concluded that there was no difference between learning outcomes using inquiry and PjBL models for PGSD students.
\end{abstract}

Keywords: inquiry, PjBL, elementary school, citizenship education

\begin{abstract}
Abstrak: Tujuan penelitian untuk menemukan perbandingan antara hasil belajar menggunakan model pembelajaran inkuiri dan PjBL. Hipotesis penelitian yaitu ada perbedaan (Ha) dan tidak ada perbedaan (Ho) dalam hasil belajar mahasiswa PGSD. Penelitian ini menggunakan metode kuantitatif dengan desain penelitian eksperimen semu. Populasi yang diteliti yaitu semua mahasiswa sarjana PGSD Universitas Negeri Malang (UM). Sampel diambil dengan teknik purposive sampling. Teknik analisis data menggunakan uji-t dengan bantuan program SPSS. Hasil penelitian menunjukkan bahwa Ho diterima sehingga dapat disimpulkan tidak ada perbedaan antara hasil belajar menggunakan model inkuiri dan PjBL pada mahasiswa PGSD.
\end{abstract}

Kata Kunci: inkuiri, PjBL, sekolah dasar, pendidikan kewarganegaraan

Sebagaimana diamanatkan oleh Undang-Undang RepublikIndonesiaNo.20tahun2003, paragraf1 Pasal 1 tentang Sistem Pendidikan Nasional, "pendidikan berarti upaya yang sadar dan terencana dalam menciptakan lingkungan belajar dan proses belajar sehingga peserta didik akan dapat mengembangkan potensi penuh mereka untuk memperoleh kekuatan spiritual dan religius, mengembangkan kontrol diri, kepribadian, kecerdasan, akhlak dan karakter mulia dan keterampilan yang dibutuhkan seseorang demi dirinya sendiri, untuk masyarakat, untuk bangsa, dan untuk negara. " Ini menunjukkan bahwa peserta didik yang berkualitas dihasilkan dari pendidikan yang berkualitas.

Paragraf 2 Pasal 40 Undang-Undang Republik Indonesia No. 20 tahun 2003 menetapkan bahwa salah satu tanggung jawab guru dan tenaga akademik adalah menciptakan situasi pembelajaran yang bermakna, ceria, kreatif, dinamis, dan dialogis. Selain itu, mereka juga harus memiliki komitmen profesional untuk mengembangkan kualitas pendidikan. Oleh karena itu, guru sebagai 
pendidik diharapkan dapat memilih model dan metode pembelajaran yang tepat karena mereka dapat berfungsi sebagai fasilitator kegiatan pembelajaran. Pembelajaran berbasis kurikulum 2013 menggunakan pendekatan pembelajaran berbasis ilmiah. Pendekatan semacam itu melibatkan beberapa model pembelajaran, yaitu pembelajaran penemuan, pembelajaran berbasis proyek, pembelajaran berbasis masalah, dan pembelajaran inkuiri (Peraturan Menteri Pendidikan dan Kebudayaan No. 103 tahun 2014).

Feral Ogan-Bekiroglu dan Arzu Arslan (2014) telah menyelesaikan penelitian mereka tentang Efek dari Model Berbasis Penyelidikan pada Hasil Belajar Siswa. Hasilnya adalah para peserta di kedua kelompok tidak menunjukkan perbedaan dalam skor keseluruhan keterampilan proses ilmiah dan pengetahuan konseptual mereka setelah kegiatan. Namun, ketika skor keterampilan proses ilmiah mereka dibandingkan dalam hal lima dimensi dalam melalui tes, ditemukan bahwa sementara kelompok kontrol meningkatkan kinerja mereka secara signifikan dalam dimensi mengidentifikasi variabel dan menyatakan hipotesis, kelompok eksperimen meningkatkan skor mereka secara signifikan dalam dua dimensi ini serta dalam dimensi definisi operasional dan interpretasi data dan grafik. Studi ini menambah penelitian terbatas di bidang model berbasis penyelidikan dengan memeriksa efektivitasnya ketika digunakan di kelas sains (Ogan-Bekiroğlu \& Arslan, 2014).

Hasil penelitian yang dilakukan oleh (Sochibin, Dwijananti, \& Marwoto, 2009) tentang penerapan metode pembelajaran inkuiri terbimbing memiliki hasil bahwa metode ini dapat meningkatkan penguasaan konseptual dan mengembangkan kemampuan berpikir kritis mereka. Penelitian lain yang dilakukan oleh (Dewi, Dantes, \& Sadia, 2013) tentang pengaruh model pembelajaran inkuiri terbimbing juga menunjukkan bahwa penerapan model pembelajaran inkuiri terbimbing dapat secara signifikan meningkatkan sikap ilmiah siswa sekolah dasar IV dan hasil belajar di Kecamatan Kaliuntu. Temuan penelitian tersebut mengungkapkan bahwa penerapan model pembelajaran Guided Inquiry dapat meningkatkan keterampilan berpikir kritis siswa, sikap ilmiah, kegiatan pembelajaran, dan hasil.

Ciftci (2015) telah meneliti tentang Efek Pembelajaran Berbasis Proyek dalam Pendidikan Studi Sosial. Tujuan dari penelitian ini adalah untuk menguji pengaruh Pembelajaran Berbasis Proyek terhadap sikap siswa untuk mengajar pelajaran sosial di kelas enam di sekolah dasar. Penelitian ini dilakukan di sebuah sekolah dasar di Konya dengan total 41 siswa. Menurut hasil pre-test dan post-test dari kelompok kontrol, siswa yang menerima dengan pendekatan tradisional diterapkan dan kelompok eksperimen, dimana siswa menerima pembelajaran berbasis proyek, tidak ada perbedaan yang signifikan antara sikap siswa terhadap studi sosial.

Kesimpulan penelitian yang dilakukan oleh Inthachot, Sopeerak, \& Rapai (2013) menunjukkan tiga kelompok faktor yang terlibat dalam pengembanganmodelpembelajaranu-learningmenggunakan pendekatan pembelajaran berbasis proyek untuk meningkatkan keterampilan menciptakan-inovasi peserta didik ke-21. Hasil penelitian yang dilakukan oleh (Ferawati, 2014) tentang PjBL menunjukkan bahwa penerapan strategi PjBL yang dibantu oleh modul dapat meningkatkan pengetahuan, sikap, dan perilaku siswa. Penelitian lain dilakukan oleh (I Made, 2014) tentang efek model pembelajaran berbasis proyek (PjBL) pada hasil belajar biologi juga disajikan bahwa model pembelajaran berbasis proyek lebih baik daripada model instruksi langsung dalam meningkatkan hasil belajar siswa. Artikel lain memiliki kesimpulan bahwa pembelajaran berbasis proyek adalah pendekatan yang dipilih dengan cermat untuk menunjukkan bentuk yang harus diambil oleh sistem pendidikan saat ini (Tasc1, 2015a). Pembelajaran berbasis proyek, menganggap proyek bukan sebagai tujuan tetapi alat menekankan aspek proses pembelajaran daripada aspek produk. García (2016) pada $2^{\text {nd }}$ International Conference on Higher Education Advances mengatakan, "Hasil analisis kami menunjukkan peningkatan yang signifikan dalam ketiga jenis pengetahuan. Guru dapat menggunakan lebih banyak ide, mengusulkan lebih banyak tindakan dan menempatkannya dalam konteks tertentu. Hasil kami mendukung pembelajaran berbasis proyek di lingkungan virtual untuk mendorong pembelajaran yang bermakna."

Pada dasarnya, belajar adalah proses yang berkesinambungan untuk mengubah perilaku konstruktif siswa (Nanang \& Cucu, 2009). Belajar adalah proses yang melibatkan entitas individu sebagai unit suatu organisme, sehingga terjadi perubahan dalam pengetahuan, keterampilan, dan perilakunya (Dimyatidkk., 2013). Berdasarkan sudut pandang di atas, pembelajaran dapat didefinisikan 
sebagai proses konstruktif yang mengembangkan kemampuan berpikir siswa untuk mendapatkan perubahan dalam pengetahuan, keterampilan, dan sikap. Ini sesuai dengan pembelajaran konstruktivis. Berdasarkan pendapat Nanang \& Cucu (2009), tujuan pembelajaran konstruktivis adalah "untuk membangun pemahaman baru yang memerlukan kegiatan kreatif-produktif dalam konteks nyata yang mendorong siswa untuk berpikir, memikirkan kembali, dan kemudian menunjukkan."

Belajar adalah faktor penting dalam implementasi pendidikan. Pembelajaran didefinisikan sebagai proses yang dilaksanakan oleh guru untuk membuat siswa belajar sehingga mereka dapat memperoleh dan memproses pengetahuan, keterampilan, dan sikap baru (Dimyati dkk., 2013). Berdasarkan definisi tersebut, diketahui bahwa pembelajaran bertujuan untuk membuat siswa belajar dalam rangka memperluas pengetahuan, keterampilan, dan sikap mereka. Namun, ini tentu bukan proses yang mudah. Guru yang menerapkan proses pembelajaran dituntut untuk kreatif dalam memberikan beragam aktivitas dalam proses pembelajaran. Persyaratan bagi seorang guru untuk menjadi kreatif sematamata bertujuan untuk mengembangkan kemampuan siswa, baik mengenai pengetahuan, keterampilan, atau sikap yang mereka butuhkan untuk masyarakat, bangsa, dan negara.

Tujuanutamamodelpembelajaraninkuiriadalah untuk mendorong siswa dalam mengembangkan disiplin intelektual dan keterampilan penalaran mereka dan untuk mengajukan pertanyaan dan untuk mendapatkan jawaban berdasarkan rasa ingin tahu mereka. Model pembelajaran inkuiri adalah bentuk pendekatan yang berorientasi pada siswa karena memberikan peran dominan pada siswa dalam proses pembelajaran. Model berbasis inkuiri dapat membantu guru dalam mempersiapkan pelajaran serta memenuhi beragam kebutuhan gaya belajar peserta didik (Alameddine \& Ahwal, 2016). Melalui model ini, guru dapat mempersiapkan pembelajar mereka untuk pelajaran melalui pertanyaan yang disiapkan yang akan memotivasi peserta didik untuk 'mencari tahu' dan 'mencari kebenaran'.

Pembelajaran berbasis inkuiri (IBL) memiliki pertanyaan, ide, dan refleksi peserta didik di pusat pengalaman belajar peserta didik. Ini memiliki moto konfusianisme "katakan padaku dan aku lupa, tunjukkan padaku dan aku ingat, libatkan aku dan aku mengerti" di jantung prosedurnya. Taylor \&
Bilbrey mengemukakan bahwa melalui penyelidikan, peserta didik beralih dari mengumpulkan data dan lebih ke arah memperoleh pengetahuan yang berguna yang berguna (Alameddine \& Ahwal, 2016). Ini menjadikan pelajar warga negara abad ke-21 yang merupakan pemikir kritis dan pemecah masalah (Alameddine \& Ahwal, 2016). Pendekatan pendidikan berbasis proyek, setelah arsitektur, yang merupakan titik asalnya, telah mulai digunakan untuk meningkatkan prestasi sekolah teknik dan industri, pendidikan pertanian, dan kemudian oleh guru sains dan kerajinan. Kemudian, pendekatan ini telah digunakan untuk meningkatkan prestasi di bidang-bidang seperti hukum, kedokteran, teknik, jurnalisme dan pelatihan bahasa asing (Knoll, 1997 dalam (Tasc1, 2015a)).

Penelitian Panasan \& Nuangchalerm (2010) tentang perbedaan pembelajaran dan penyelidikan berbasis proyek, menyimpulkan bahwa rencana untuk organisasi kegiatan pembelajaran berbasis proyek dan penyelidikan yang tepat efisien dan efektif. Para siswa dalam 2 kelompok tidak menunjukkan prestasi belajar yang berbeda, keterampilan proses sains, dan pemikiran analitis. Menurut penjelasan di atas, dapat diidentifikasi bahwa penerapan model inkuiri maupun PjBL memberikan manfaat tertentu dalam mengoptimalkan potensi siswa. Fakta tersebut perlu dipelajari pada mahasiswa untuk mengidentifikasi dampak dari implementasi tersebut pada mahasiswa. Selain itu, perlu untuk memeriksa dua model pembelajaran untuk menentukan model mana yang lebih efisien dalam meningkatkan hasil belajar mahasiswa.

\section{METODE}

Penelitian ini adalah penelitian kuantitatif teknik eksperimental, menggunakan desain quasieksperimental. Populasi penelitian ini adalah seluruh mahasiswa PGSD UM. Dalam rangka menjaga kesamaan karakteristik responden penelitian, maka diberlakukan kriteria karakteristik responden sebagai berikut: (1) Mahasiswa tersebut merupakan mahasiswa PGSD UM tahun angkatan 2014, (2) masih aktif sebagai mahasiswa PGSD UM, (3) lokasi perkuliahan di kampus 2 UM, Sawojajar.

Teknik pengambilan sampel dilakukan dengan cara purposive sampling, yakni teknik pengambilan sampel berdasarkan tujuan tertentu (Sukmadinata, 2013:254). Penarikan sampel pada penelitian ini membutuhkan kelas kontrol dan kelas eksperimen. 
Penentuan kelas yang akan dijadikan sampel penelitian dilihat berdasarkan tingkat kemampuan yang dimiliki oleh masing-masing kelas sampel. Adapun yang dijadikan bahan pertimbangan dalam pemilihan kelas sampel penelitian ini adalah hasil studi rata-rata kelas yang ada pada tiap kelas populasi. Desain penelitian yang digunakan ditunjukkan pada Gambar 1.

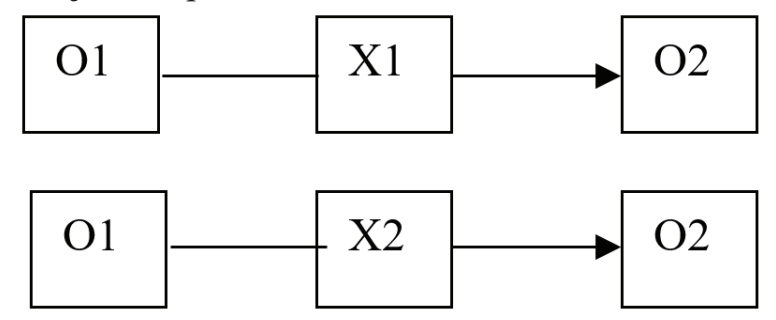

Keterangan:

O1: pre-test disediakan sebelum kegiatan belajar

O2: post-test disediakan sesudah kegiatan belajar

$\mathrm{X} 1$ : perlakuan model pembelajaran inkuiri dalam kelompok eksperimen

$\mathrm{X} 2$ : perlakuan model PjBL pada kelompok kontrol

\section{Gambar 1. Metode Desain Kuasi Eksperimental}

Teknik penelitian yang digunakan yaitu observasi dan tes. Instrument penelitian yang digunakan yaitu lembar observasi untuk mengetahui penerapan model pembelajaran yang digunakan, soal dan kunci jawaban tes sebagai produk hasil belajar pada aspek kognitif, lembar observasi psikomotor untuk mengetahui keterampilan mahasiswa berdasarkan perlakuan yang dilakukan, dan lembar observasi sikap saat perlakuan diberikan.

Tujuan penelitian ini adalah untuk mengidentifikasi perbedaan antara aplikasi penyelidikan dan PjBLmodelsin untuk mengetahui mana yang lebih efisien dari yang lain. Informasi dari tingkat efektivitas tersebut dikumpulkan dari hasil belajar siswa. Oleh karena itu, data dianalisis menggunakan teknik analisis data t-test melalui SPSS ver 16.

\section{HASIL}

Prosedur penyelidikan dan model PjBL diselesaikan di ruang kelas dalam periode 3 minggu pada tahun 2017. Kegiatan pembelajaran dilakukan $100 \%$ oleh prosedur sintaksis khusus model di setiap kelas. Post-test diberikan kepada siswa pada minggu ke-3 untuk mengukur kemajuan pengetahuan mereka. Hasil pre-test dan post-test dari kelas eksperimen yang diperlakukan oleh Project Based Learning (PjBL) dan model pembelajaran inkuiri disajikan pada Tabel 1.

Berdasarkan Tabel 1, dapat dilihat bahwa setiap kelas eksperimen memiliki hasil pre-test yang serupa. Sementara itu, setelah post-test, kita dapat mengetahui perbedaan antara pre dan post-test di setiap kelas eksperimen menggunakan model pembelajaran $\mathrm{PjBL}$ dan Inkuiri. Berdasarkan tabel, diketahui bahwa kelas yang menggunakan model pembelajaran Inkuiri ternyata memiliki perbedaan sebelum dan sesudah tes yang positif (naik) dibandingkan dengan kelas dengan model pembelajaran PjBL. Perbedaan antara kelas pre dan post-test dengan model $\mathrm{PjBL}$ sebesar 4,88 dan kelas dengan model inkuiri lebih tinggi 1,57 yaitu sebesar 6,45.

Menurut data pada Tabel 2, dapat diketahui bahwa tingkat Signifikansi adalah 0,109 sehingga lebih besar dari 0,05 . Oleh karena itu, dapat disimpulkan bahwa Ho diterima dan Ha ditolak. Dengan demikian, dapat disimpulkan bahwa tidak ada perbedaan antara hasil belajar siswa Pendidikan Guru Sekolah Dasar dengan menggunakan model inkuiri dan PjBL.

Dasar-dasar pengambilan keputusan: (1) Jika nilai signifikansi atau Sig. (2-tailed) $>0,05$, Ho diterima, dan Ha ditolak. (2) Jika nilai signifikansi atau Sig. (2-tailed) $<0,05$, Ho ditolak, dan $\mathrm{Ha}$ diterima.

\section{PEMBAHASAN}

Pembelajaran merupakan proses yang dilaksanakan oleh guru untuk mendorong siswa untuk belajar untuk memperoleh dan memproses pengetahuan, keterampilan, dan sikap baru (Dimyati et al., 2013). Dari definisi tersebut, dapat diketahui bahwa pembelajaran ditujukan untuk membuat siswa belajar sehingga mereka dapat mengembangkan semua

Tabel 1. Hasil Pre-Test dan Post-Test Kelas Eksperimen

\begin{tabular}{ccccc}
\hline \multirow{2}{*}{ Kelas } & \multicolumn{3}{c}{ Rata-rata } & \multirow{2}{*}{ Keterangan } \\
\cline { 2 - 4 } & Pre-Test & Post Test & Perbedaan & meningkat \\
PjBL & 59.64 & 64.52 & 4.88 & meningkat \\
Inkuiri & 53.42 & 59.87 & 6.45 & \\
\hline
\end{tabular}


kemampuan mereka, baik dalam hal pengetahuan, keterampilan, atau sikap untuk masyarakat, bangsa, dan negara. Salah satu faktor penentu dalam keberhasilan proses pembelajaran adalah model pembelajaran yang digunakan. Model pembelajaran adalah seluruh rangkaian kegiatan pembelajaran yang dilakukan dari awal hingga akhir pembelajaran. Ada ratusan model pembelajaran yang bisa digunakan. Namun, tidak semuanya cocok untuk semua program studi, dan kompetensi/materi pembelajaran. Model inkuiri dan Pembelajaran Berbasis Proyek (PjBL) adalah contoh model pembelajaran yang sesuai untuk pendidikan kewarganegaraan.

Pembelajaran menggunakan model inkuiri dan model PjBL dilaksanakan pada pembelajaran di kelas dalam periode 3 minggu. Kegiatan pembelajaran dilaksanakan $100 \%$ sesuai dengan sintaks masingmasing model. Sebagai model pembelajaran, pembelajaran inkuiri memiliki prosedur sintaksis yang normal termasuk orientasi, perumusan masalah, proposal hipotesis, pengumpulan data, pengujian hipotesis, dan menarik kesimpulan (Sanjaya, 2011). Kelas eksperimen lainnya diperlakukan dengan menggunakan model Project Based Learning (PjBL). Menurut Keputusan Menteri Pendidikan dan Kebudayaan (Nuh, 2013), Project Based Learning (PjBL) adalah model pembelajaran yang memanfaatkan proyek/kegiatan sebagai media. Para siswa dituntut untuk mengeksplorasi, mengevaluasi, menafsirkan, dan mensintesis informasi untuk menghasilkan berbagai bentuk hasil belajar (pengetahuan, keterampilan, dan sikap). Dengan demikian, model pembelajaran tersebut memberi guru kesempatan untuk mengelola kegiatan belajar di kelas dengan melibatkan proyek (Wena, 2011). Pernyataan ini juga didukung oleh Thomas, 2000 dalam (Holmes, 2013) yang menyatakan bahwa pembelajaran berbasis proyek memfasilitasi siswa untuk belajar dalam situasi nyata dari suatu masalah, yang dapat menghasilkan pengetahuan dan kemampuan permanen untuk mengatur proyek selama pembelajaran.

Pendekatan pembelajaran berbasis proyek telah menjadi pendekatan pendidikan yang melampirkan informasi semakin banyak karena keunggulan pendidikan yang berpusat pada siswa dalam beberapa tahun terakhir. Fondasi dari pendekatan ini terkait erat dengan teori konstruktivisme oleh Dewey. Pembelajaran berbasis proyek adalah pendekatan yang dipilih dengan cermat untuk menunjukkan bentuk yang harus diambil oleh sistem pendidikan saat ini. Pembelajaran berbasis proyek, yang menganggap proyek bukan sebagai tujuan tetapi alat menekankan aspek proses pembelajaran daripada aspek produk (Tasc1, 2015b).

Berdasarkan temuan penelitian, hasil pre-test dan post-test menunjukkan bahwa model pembelajaran inkuiri dapat meningkatkan pemahaman konseptual siswa dalam matakuliah Pendidikan Kewarganegaraan untuk Sekolah Dasar. Fakta tersebut diperoleh dari peningkatan skor rata-rata post-test dari rata-rata skor pre-test kelas, yaitu dari 53,42 menjadi 59,87 dengan selisih 6,45. Terungkap bahwa model pembelajaran inkuiri dapat meningkatkan hasil belajar siswa. Selain itu, 29 mahasiswa (76,32\%) mengalami peningkatan dalam hasil belajar mereka dengan menggunakan model pembelajaran inkuiri. Namun, ada sembilan mahasiswa $(23,68 \%)$ yang mengalami penurunan hasil belajar. Sementara itu, tidak ada mahasiswa yang memiliki hasil yang sama antara pre-test dan post-test. Ini memperkuat fakta bahwa model pembelajaran

Tabel 2. Hasil $t$-test Menggunakan SPSS 16

\begin{tabular}{|c|c|c|c|c|c|c|c|c|c|c|}
\hline & & \multicolumn{8}{|c|}{ Group Statistics } & \\
\hline \multirow{3}{*}{\multicolumn{2}{|c|}{ NILAI }} & A & $\mathrm{N}$ & \multicolumn{2}{|c|}{ Mean } & \multicolumn{2}{|c|}{ Std. Deviation } & \multicolumn{2}{|c|}{ Std. Error Mean } & \\
\hline & & A & 38 & \multicolumn{2}{|c|}{59.8684} & \multicolumn{2}{|c|}{14.86365} & \multicolumn{2}{|c|}{2.41120} & \\
\hline & & B & 42 & \multicolumn{2}{|c|}{64.5238} & & 0.63872 & \multicolumn{2}{|c|}{1.64159} & \\
\hline \multicolumn{11}{|c|}{ Independent Samples Test } \\
\hline & & & \multicolumn{3}{|c|}{$\begin{array}{l}\text { Levene's Test for } \\
\text { Equality of Variances } \\
\end{array}$} & \multicolumn{4}{|c|}{ t-test for Equality of Means } & \\
\hline & & & \multirow[t]{2}{*}{$\mathrm{F}$} & \multirow[t]{2}{*}{ Sig. } & \multirow[t]{2}{*}{$\mathrm{T}$} & \multirow[t]{2}{*}{$\mathrm{df}$} & \multirow[t]{2}{*}{ Sig. (2-tailed) } & \multirow[t]{2}{*}{$\begin{array}{c}\text { Mean } \\
\text { Difference }\end{array}$} & \multirow[t]{2}{*}{$\begin{array}{l}\text { Std. Error } \\
\text { Difference }\end{array}$} & $\begin{array}{l}95 \% \text { Confidence } \\
\text { Interval of the } \\
\text { Difference }\end{array}$ \\
\hline & & & & & & & & & & Lower Upper \\
\hline \multirow{2}{*}{ NILAI } & $\begin{array}{l}\text { Equa } \\
\text { assur }\end{array}$ & & 1.541 & .218 & -1.622 & 78 & .109 & -4.65539 & 2.86971 & -10.36854 .05776 \\
\hline & $\begin{array}{l}\text { Equa } \\
\text { not a }\end{array}$ & & & & -1.596 & 66.379 & .115 & -4.65539 & 2.91697 & $\begin{array}{ll}-10.47869 & 1.16791 \\
\end{array}$ \\
\hline
\end{tabular}


inkuiri tepat untuk diterapkan dalam kursus Pendidikan Kewarganegaraan untuk Sekolah Dasar.

Tahap sintaksis implementasi model PjBL terdiri dari penetapan pertanyaan dasar, merancang rencana proyek, mengatur jadwal, memantau siswa dan kemajuan proyek, menguji hasil, dan mengevaluasi pengalaman. Model Pembelajaran Berbasis Proyek (PjBL) juga terbukti mampu meningkatkan hasil belajar siswa dalam matakuliah Pendidikan Kewarganegaraan untuk Sekolah Dasar. Hal itu dapat dilihat dari hasil pre-test dan posttest dari kelas eksperimen. Rata-rata skor pre-test klasikal, yaitu 59.64, menunjukkan peningkatan pada post-test setelah penerapan model PjBL, yaitu menjadi 64.52. Berdasarkan data yang diperoleh, penggunaan model PjBL menghasilkan 21 mahasiswa atau $50 \%$ dari mahasiswa mengalami peningkatan dalam hasil post-test. Sementara itu, ada juga beberapa mahasiswa yang mengalami penurunan skor post-test mereka, yaitu 11 mahasiswa (26,19\%). Ada juga mahasiswa yang memiliki hasil yang sama, yaitu sepuluh mahasiswa $(23,81 \%)$. Berdasarkan data di atas, dapat diidentifikasi bahwa model PjBL juga dapat meningkatkan hasil belajar siswa

Efek penerapan model inkuiri dan Pembelajaran Berbasis Proyek (PjBL) dapat dilihat dari pengolahan data yang dikelola melalui SPSS. Beberapa hal yang diketahui dapat digunakan untuk menentukan apakah hipotesis diterima atau tidak. Hipotesis yang diajukan adalah $\mathrm{Ha}$ (ada perbedaan antara hasil belajar siswa Pendidikan Guru Sekolah Dasar dengan menggunakan model inkuiri dan PjBL) versus Ho (tidak ada perbedaan antara hasil belajar siswa Pendidikan Guru Sekolah Dasar dengan menggunakan inkuiri dan model PjBL). Berdasarkan hasil data di atas, dapat dilihat bahwa Ho diterima dan Ha ditolak. Dengan demikian, dapat disimpulkan bahwa tidak ada perbedaan antara hasil belajar mahasiswa PGSD dengan menggunakan model inkuiri dan PjBL. Itu dimungkinkan karena kedua model inkuiri dan $\mathrm{PjBL}$ menawarkan prosedur ilmiah. Oleh karena itu, temuan penelitian ini menunjukkan bahwa tidak ada perbedaan antara hasil belajar siswa yang diobati dengan model inkuiri dan model PjBL.

Penelitian yang telah dilakukan menunjukkan hasil bahwa tidak ada perbedaan yang signifikan antara penggunaan model pembelajaran inkuri dan PjBL pada matakuliah Pendidikan
Kewarganegaraan SD untuk mahasiswa PGSD UM. Hasil ini mendukung penelitian terdahulu yang dilakukan Panasan \& Nuangchalerm (2010) bahwa kedua model pembelajaran memberikan efek positif terhadap pembelajaran. Secara terpisah, model pembelajaran inkuiri dapat meningkatkan hasil belajar siswa Pendidikan Guru Sekolah Dasar juga sesuai dengan penelitian-penelitian terdahulu (Ogan-Bekiroğlu \& Arslan, 2014; Sochibin dkk., 2009; Dewi dkk., 2013). Hasil penelitian ini juga menunjukkan bahwa pembelajaran menggunakan model PjBL dapat meningkatkan hasil belajar siswa Pendidikan Guru Sekolah Dasar, seesuai dengan penelitian terdahulu oleh Ferawati (2014) dan García (2016).

\section{SIMPULAN DAN SARAN}

\section{Simpulan}

Menurut penelitian, diketahui bahwa ada perbedaan antara hasil belajar siswa Pendidikan Guru Sekolah Dasar setelah menggunakan model pembelajaran Inkuiri dan model PjBL. Skor ratarata kelas eksperimen yang menggunakan model Inkuiri memiliki rentang perbedaan yang lebih besar, yaitu 6,45 , dibandingkan dengan kisaran perbedaan yang ditemukan di kelas yang menggunakan model PjBL, yaitu 4,88. Namun, hasil pengolahan data oleh SPSS 16 mengungkapkan tingkat signifikansi yang lebih tinggi dari 0,05. Dengan demikian, dapat disimpulkan bahwa Ho diterima dan Ha ditolak. Oleh karena itu, dapat dikonfirmasikan bahwa tidak ada perbedaan dalam hasil pembelajaran antara mahasiswa yang menerima model pembelajaran inkuiri dan mereka yang menerima model PjBL.

\section{Saran}

Berdasarkan hasil penelitian, disarankan bagi tenaga pendidik untuk melaksanakan kegiatan pembelajaran menggunakan model inkuiri dan PjBL karena dapat memberikan dampak positif bagi peserta didik.

\section{DAFTAR RUJUKAN}

Alameddine, M. M., \& Ahwal, H. W. (2016). Inkuiri Based Teaching in Literature Classrooms. Procedia - Social and Behavioral Sciences, 232, 332-337. https://doi.org/10.1016/j. sbspro.2016.10.031 
Ciftci, S. (2015). The Effects of Using ProjectBased Learning in Social Studies Education to Students' Attitudes towards Social Studies Courses. Procedia - Social and Behavioral Sciences, 186, 1019-1024. https://doi. org/10.1016/j.sbspro.2015.04.205

Dewi, N. L., Dantes, N., \& Sadia, I. W. (2013). Pengaruh Model Pembelajaran Inkuiri Terbimbing Terhadap Sikap Ilmiah dan Hasil Belajar IPA. Jurnal Penelitian Pascasarjana Undhiksa, 3. Retrieved from http://119.252.161.254/e-journal/index.php/ jurnal_pendas/article/view/512

Dimyati, Mudjiono, \& Pusat Perbukuan (Indonesia). (2013). Belajar dan pembelajaran (Cetakan kelima). Jakarta: Rineka Cipta: Departemen Pendidikan \& Kebudayaan.

Ferawati. (2014). Penerapan strategi Project Based Learning (PjBL) berbantuan modul pengelolaan sampah berbasis $6 M$ untuk meningkatkan pengetahuan, sikap, dan perilaku siswa menuju program sekolah adiwiyata di SMP Negeri 15 Kota Malang. Retrieved from http://library.um.ac.id/ptk/ index.php? $\mathrm{mod}=$ detail\&id $=65301$

García, C. (2016). Project-based Learning in Virtual Groups - Collaboration and Learning Outcomes in a Virtual Training Course for Teachers. Procedia - Social and Behavioral Sciences, 228, 100-105. https://doi.org/10.1016/j. sbspro.2016.07.015

Holmes, N. (2013). Makalah PBL(Project Based Learning). Retrieved from http://blogholmesnababan.blogspot.com/2013/03/ makalah-pbl-project-based-learning.html

I Made, W. J.(2014). Pengaruh Model Pembelajaran Berbasis Proyek (PjBL) terhadap Hasil Belajar Biologi ditinjau dari Gaya Belajar Siswa SMA. Retrieved from http://pasca.undiksha. ac.id/e-journal/index.php/jurnal ipa/article/ viewFile/1300/1002

Inthachot, M., Sopeerak, S., \& Rapai, N. (2013). The Development of a U-learning Instructional Model Using Project based Learning Approach to Enhance Students' Creating-innovation Skills. Procedia - Social and Behavioral Sciences, 103, 1011-1015. https://doi. org/10.1016/j.sbspro.2013.10.426

Nanang, H., \& Cucu, S. (2009). Konsep Strategi Pembelajaran. Bandung: PT. Refika Aditama.

Nuh, M. (2013). Peraturan Menteri Pendidikan Dan Kebudayaan Republik Indonesia Nomor 65 Tahun 2013 Tentang Standar Proses Pendidikan Dasar Dan Menengah. Kemendikbud.

Ogan-Bekiroğlu, F., \& Arslan, A. (2014). Examination of the Effects of Model-based Inkuiri on Students' Outcomes: Scientific Process Skills and Conceptual Knowledge. Procedia - Social and Behavioral Sciences, 141, 1187-1191. https://doi.org/10.1016/j. sbspro.2014.05.202

Panasan, M., \& Nuangchalerm, P. (2010). Learning Outcomes of Project-Based and Inkuiri-Based Learning Activities. Journal of Social Sciences, 6 (2)(Science Publications), 252-255.

Sanjaya, W. (2011). Strategi Pembelajaran Berorientasi Standar Proses Pendidikan. Jakarta: Kencana Perdana Media.

Sochibin, A., Dwijananti, P., \& Marwoto, P. (2009). Penerapan Model Pembelajaran Inkuiri Terpimpin untuk Peningkatan Pemahaman dan Keterampilan Berpikir Kritis Siswa SD. JURNAL PENDIDIKAN FISIKA INDONESIA, $5,96-101$.

Tasc1, B. G. (2015a). Project Based Learning from Elementary School to College, Tool: Architecture. Procedia - Social and Behavioral Sciences, 186, 770-775. https://doi. org/10.1016/j.sbspro.2015.04.130

Tasc1, B. G. (2015b). Project Based Learning from Elementary School to College, Tool: Architecture. Procedia - Social and Behavioral Sciences, 186, 770-775. https://doi. org/10.1016/j.sbspro.2015.04.130

Wena, M. (2011). Strategi Pembelajaran Inovatif Kontemporer. Jakarta: Bumi Aksara. 